\title{
ANALISIS NERACA AIR DI KOTA TARAKAN PROVINSI KALIMANTAN UTARA Sudirman Sirait ${ }^{1}$, Hendris Hendris ${ }^{2}$
}

\author{
${ }^{1}$ Program Studi Agroteknologi Fakultas Pertanian Universitas Borneo Tarakan \\ ${ }^{2}$ Program Studi Agribisnis Fakultas Pertanian Universitas Borneo Tarakan \\ Jalan Amal Lama Nomor 1 Kelurahan Pantai Amal, Kota Tarakan, 77123. \\ E-Mail: sudirsirait@gmail.com
}

Receive: 25 September 2019

Accepted: 12 Oktober 2019

\begin{abstract}
Water needs for agricultural activities in Tarakan City which are located at the geographical coordinates of $117^{\circ} 34^{\prime}-$ $117^{\circ} 38^{\prime}$ East Longitude and $3^{\circ} 19^{\prime}-3^{\circ} 20^{\prime}$ Nort Latitude are still dependent on rainfall, so that there is potential for uncertainty in water availability for plant. Water is one of the absolute factors needed by the agricultural sector for growth and development of plant that affects crop production. Production of agricultural products will decrease if the plants be through water stress. The water balance analysis method is a method that can know the level of carrying capacity of water resources, especially in water storage capacity for groundwater recharge. This study aims to analyze the water balance in Tarakan City to occupy plant water needs. This research was divided into several stages, which are the literature study, the data collection, and the data analysis. The results showed that during the period of 2008-2017 the Tarakan City area had a reliable rainfall value of $3497.68 \mathrm{~mm} /$ year, an average ETp value of $41.65 \mathrm{~mm} / \mathrm{month}$, a total $\mathrm{CH}$ value of more than $2997.88 \mathrm{~mm}$, runoff value of $1630.34 \mathrm{~mm}$, and groundwater recharge value of $1367.54 \mathrm{~mm}$. Based on the results of the water balance analysis, that the Tarakan City area does not encounter a water deficit so that it can support crop cultivation activities and fulfill crop water needs to increase productivity.
\end{abstract}

Key words: Groundwater Recharge, Rainfall, Run-Off, Water Balance, Water Resources

\begin{abstract}
ABSTRAK
Kebutuhan air untuk kegiatan pertanian di Kota Tarakan yang terletak pada koordinat geografis $117^{\circ} 34^{\prime}-117^{\circ} 38^{\prime}$ Bujur Timur dan $3^{\circ} 19^{\prime}-3^{\circ} 20^{\prime}$ Lintang Utara masih tergantung pada air hujan, sehingga berpotensi terjadinya ketidakpastian ketersediaan air untuk tanaman. Air merupakan salah satu faktor mutlak yang diperlukan sektor pertanian untuk pertumbuhan dan perkembangan tanaman yang mempengaruhi produksi tanaman. Produksi hasil pertanian akan menurun jika tanaman mengalami cekaman air. Metode analisis neraca air merupakan suatu metode yang dapat mengetahui tingkat daya dukung suatu wilayah terutama daya dukung sumberdaya air untuk kegiatan pertanian sehingga dapat memberikan rekomendasi upaya pengelolaan limpasan dan pengisian air tanah. Penelitian ini bertujuan untuk menganalisis neraca air di Kota Tarakan untuk memenuhi kebutuhan air tanaman. Penelitian ini dibagi dalam beberapa tahapan yaitu studi pustaka, pengumpulan data, dan analisis data. Hasil penelitian menunjukkan bahwa selama periode 2008-2017 wilayah Kota Tarakan memiliki nilai curah hujan andalan 3497,68 mm/tahun, nilai ETp rata-rata 41,65 mm/bulan, total nilai $\mathrm{CH}_{\text {lebih }} 2997,88 \mathrm{~mm}$, nilai limpasan $1630,34 \mathrm{~mm}$, dan nilai pengisian air tanah 1367,54 mm. Berdasarkan hasil analisis neraca air, bahwa wilayah Kota Tarakan tidak mengalami defisit air sehingga dapat mendukung kegiatan budidaya tanaman dan memenuhi kebutuhan air tanaman untuk meningkatkan produktivitas.
\end{abstract}

Kata kunci: Curah Hujan, Limpasan, Neraca Air, Pengisian Air Tanah, Sumberdaya Air

\section{PENDAHULUAN}

Secara geografis wilayah Kota Tarakan berada antara $117^{\circ} 34^{\prime}-117^{\circ} 38^{\prime}$ Bujur Timur dan $3^{\circ} 19^{\prime}-3^{\circ} 20^{\prime}$ Lintang Utara yang terdiri dari 4 Kecamatan dan 20 Kelurahan serta mempunyai luas daratan 250,80 $\mathrm{Km}^{2}$ dan luas lautan 406,53 $\mathrm{Km}^{2}$. Kota Tarakan mempunyai wilayah dengan kelas ketinggian di antara 7-25 meter di atas permukaan laut $(72,41 \%)$ dan kelas ketinggian 0-7 meter di atas permukaan laut $(27,59 \%)$. Jenis tanah pada wilayah Kota Tarakan didominasi tanah latosol dengan luas
14.454 Ha atau 57,63\% dari luas tanah Kota Tarakan yang tersebar di bagian tengah pulau dan meliputi 4 kecamatan. Jenis tanah lainnya adala podsolik yang penyebarannya memanjang pada bagian barat laut tenggara dengan luas $6.897 \mathrm{Ha}(27,50 \%)$ (Pemda Kaltara 2016; Pemda Kota Tarakan 2016).

Penggunaan lahan wilayah Kota Tarakan sebagian besar merupakan pemukiman dan lahan pertanian khususnya tanaman hortikultura. Kegiatan pertanian wilayah Kota Tarakan masih menerapkan pertanian sistem tadah hujan, sehingga berpotensi terjadinya ketidakpastian ketersediaan air untuk 
tanaman. Ketersediaan air merupakan salah satu faktor mutlak yang diperlukan sektor pertanian untuk pertumbuhan dan perkembangan tanaman yang mempengaruhi produksi tanaman. Jika tanaman kekurangan air, baik pada fase vegetatif maupun generatif dapat menyebabkan terganggunya pertumbuhan tanaman, penurunan laju fotosintesis dan mengganggu distribusi asimilat sehingga mengakibatkan penurunan produktivitas tanaman. Siebert dan Döll (2010) memperkirakan bahwa ratarata hasil produksi tanaman biji-bijian dengan sistem irigasi adalah 4,4 ton/ha, sedangkan dengan sistem tadah hujan sebesar 2,7 ton/ha. Sebesar $42 \%$ dari hasil produksi tanaman biji-bijian pada umumnya berasal dari lahan irigasi dan tanpa sistem irigasi hasil produksi akan menurun sebesar $20 \%$.

Wilayah Kota Tarakan telah mengalami penurunan daya dukung sumberdaya air, hal ini dapat diamati dengan peningkatan perubahan alih fungsi lahan yaitu semakin mengecilnya luas area hutan, semakin luasnya lahan untuk pemukiman dan prasarana serta semakin banyaknya lahan kritis. Kerusakan wilayah Kota Tarakan dapat mengakibatkan kondisi kuantitas air menjadi fluktuatif antara musim penghujan dan kemarau. Penurunan daya dukung sumberdaya air pada wilayah Kota Tarakan menyebabkan terjadinya penurunan cadangan air, erosi dan tingginya laju sendimentasi. Perubahan pengisian air tanah dapat mengakibatkan ketidakseimbangan antara ketersediaan dan kebutuhan air untuk kegiatan pertanian maupun non pertanian. Dampak yang dirasakan kemudian adalah terjadinya banjir di musim penghujan dan kekeringan di musim kemarau. Hal ini mengindikasikan bahwa terjadi kehilangan air dalam jumlah besar di musim hujan dan menurunnya permukaan air tanah untuk kapasitas simpan air. Oleh karena itu, pengelolaan wilayah Kota Tarakan yang tidak memadai akan mengakibatkan rusaknya sumberdaya air pada wilayah Kota Tarakan (Asdak 2010; Arsyad 2012; Triatmodjo 2013).

Metode analisis neraca air merupakan suatu metode yang dapat mengetahui tingkat daya dukung suatu wilayah terutama perubahan kapasitas simpan air untuk pengisian air tanah berdasarkan perubahan proporsi penggunaan lahan sehingga dapat memberikan rekomendasi upaya pengelolaan limpasan dan pengisian air tanah khususnya di wilayah Kota Tarakan (Prastowo 2010; Djufry 2012; Kansil et al. 2015). Penurunan kapasitas simpan air untuk pengisian air tanah dapat mengakibatkan tidak tercukupinya kebutuhan air masyarakat sekitar oleh ketersediaan air yang ada pada wilayah tersebut. Oleh karena itu sangat diperlukan melakukan analisis neraca air wilayah Kota Tarakan Provinsi
Kalimantan Utara khususnya untuk mendukung kegiatan tatausaha tani. Tujuan dari penelitian ini adalah menganalisis neraca air wilayah Kota Tarakan berdasarkan penggunaan lahan, dan memberikan rekomendasi upaya pengelolaan limpasan dan pengisian air tanah di wilayah Kota Tarakan.

\section{Lokasi Penelitian}

\section{BAHAN DAN METODE}

Penelitian ini dilakukan pada wilayah Kota Tarakan Provinsi Kalimantan Utara yang terletak pada koordinat geografis $117^{\circ} 34^{\prime}-117^{\circ} 38^{\prime}$ BT dan $3^{\circ} 19^{\prime}-3^{\circ} 20^{\prime}$ LU. Penelitian ini dilaksanakan pada bulan September sampai dengan Desember tahun 2018. Alat dan bahan yang digunakan dalam penelitian ini adalah seperangkat komputer, software ArcGis 10 dan Cropwat 8.0, kamera digital, data iklim bulanan dan peta tata guna lahan wilayah Kota Tarakan.

\section{Prosedur Penelitian}

1. Studi pustaka

Studi pustaka digunakan untuk mempelajari berbagai metode untuk menentukan analisis neraca air berdasarkan penggunaan lahan dan parameter yang mempengaruhinya serta mengkaji kondisi ideal untuk meningkatkan daya dukung sumberdaya air suatu wilayah.

2. Pengumpulan data dan informasi

Data yang diperlukan pada penelitian ini merupakan data sekunder. Data sekunder yang dibutuhkan meliputi data iklim bulanan selama periode 2008-2017, data penggunaan lahan, data luasan wilayah Kota Tarakan, dan letak garis lintang Kota Tarakan.

3. Pengolahan dan analisis data

Pengolahan dan analisis data dilakukan untuk mengetahui pengaruh proporsi penggunaan lahan terhadap kapasitas simpan air di wilayah Kota Tarakan. Pada penelitian ini akan dilakukan analisis proporsi penggunaan lahan dan analisis komponen neraca air pada wilayah Kota Tarakan. Berikut tahapan-tahapan pengolahan dan analisis data :

1) Mengidentifikasi penutupan lahan pada wilayah Kota Tarakan tahun 2017 menggunakan software ArcGis 10.

2) Melakukan perhitungan curah hujan andalan dengan metode Weibull (Prastowo 2010; Asdak 2010; Triatmodjo 2013)

$$
\mathrm{P}=\frac{\mathrm{m}}{(\mathrm{n}+1)} \ldots(1)
$$

Curah hujan bulanan yang digunakan adalah curah hujan andalan dengan peluang $80 \%$, hal ini berarti bahwa kisaran nilai curah hujan mulai dari nol hingga nilai andalan 
dalam satu bulan memiliki peluang terlampaui sebesar $80 \%$.

3) Melakukan perhitungan evapotranspirasi dengan dengan metode Penman Monteith (Prastowo 2010; Asdak 2010; Triatmodjo 2013).

$\mathrm{ETo}=\mathrm{c} .(\mathrm{W} \cdot \mathrm{Rn}+(1-\mathrm{W}) \cdot \mathrm{f}(\mathrm{u}) \cdot(\mathrm{ea}-\mathrm{ed})(2)$

4) Menghitung selisih hujan $(P)$ dan evapotranspirasi potensial $(E T p)$. Nilai evapotranspirasi potensial (ETp atau $E T_{\text {crop }}$ ) tergantung pada nilai evapotranspirasi acuan (ETo) dan koefisien tanaman $(K c)$. Persamaan (3) digunakan untuk menghitung kebutuhan air konsumtif tanaman menurut Doorenbos dan Pruitt (1977) adalah sebagai berikut (Prastowo 2010; Asdak 2010; Triatmodjo 2013).

$$
\mathrm{ETc}=\mathrm{ETo} \times \mathrm{Kc}
$$

5) Menghitung accumulated potential water losses $(A P W L)$ dengan akumulasi air bulan ke-i $=\{$ Akumulasi air bulan ke-(i-1) + nilai P-ETP bulan i\}. Nilai negatif P-ETP menunjukkan potensi defisit air yang merupakan hasil penjumlahan setiap bulannya. Pada wilayah basah, jumlah PETP dari setiap bulan bernilai positif.

6) Menghitung kapasitas simpan air (water storage capacity (STo)) dengan menggunakan persamaan Thornthwaite dan Mather (1957).

$$
\mathrm{STo}=\left(\mathrm{KL}_{\mathrm{fc}}-\mathrm{KL}_{\mathrm{wp}}\right) \times \mathrm{dZ}(4)
$$

7) Menghitung cadangan lengas tanah (water holding capacity). Nilai cadangan lengas tanah pada awal periode dianggap sama dengan nilai cadangan lengas tanah maksimum (kapasitas simpan air tanah. Nilai cadangan lengas tanah (water holding capacity) dihitung berdasarkan persamaan Thornthwaite dan Mather (1957).

$$
\mathrm{STi}=\mathrm{ST}_{\mathrm{i}-1}+(\mathrm{P}-\mathrm{ETP})(5)
$$

8) Menghitung perubahan cadangan lengas tanah $(\Delta \mathrm{ST})$ dengan menggunakan persamaan (6) (Prastowo 2010).

$$
\Delta \mathrm{ST}=\mathrm{STi}-\mathrm{ST}_{(\mathrm{i}-1)}(6)
$$

Jika nilai cadangan lengas tanah sama dengan nilai kapasitas simpannya, diasumsikan tidak terjadi perubahan dalam penyimpanan air.
9) Menghitung evapotranspirasi aktual (ETa). Jika bulan basah $(\mathrm{P}>\mathrm{ETp})$, maka ETa $=$ ETp. Bulan kering $(\mathrm{P}<\mathrm{ETp})$, maka $\mathrm{ETa}=\mathrm{P}$ $+(-\triangle \mathrm{St})$.

10) Menghitung defisit (D), dengan menggunakan persamaan (7) (Prastowo 2010).

$$
\mathrm{D}=\mathrm{ETa}-\mathrm{ETp} . .(7)
$$

11) Menghitung $\mathrm{CH}_{\text {lebih }} / \mathrm{surplus}$ air (S) yaitu pada kondisi $\mathrm{P}>\mathrm{ETp}$, dengan persamaan Thornthwaite dan Mather (8). Perhitungan neraca air dengan persamaan Thornthwaite dapat memberikan gambaran surplus dan defisit air pada suatu wilayah. Ketika simpan air mencapai kapasitas cadangan lengas tanah (water holding capacity), kelebihan curah hujan akan dihitung sebagai surplus (Prastowo 2010; Asdak 2010; Triatmodjo 2013).

$$
\mathrm{S}=\mathrm{P}-\mathrm{ETp}-\Delta \mathrm{ST}(8)
$$

\section{HASIL DAN PEMBAHASAN}

\section{Penggunaan Lahan Wilayah Kota Tarakan}

Penggunaan lahan di kota Tarakan meliputi hutan, pemukiman, kebun campuran, lahan terbangun, dan tubuh air. Penggunaan lahan merupakan semua bentuk intervensi (campur tangan) manusia terhadap lahan dalam rangka memenuhi lingkungan hidup baik materil maupun spiritual (Arsyad 2012). Peningkatan perubahan penggunaan lahan hutan menjadi permukiman dan tanah terbuka mengakibatkan berkurangnya tutupan lahan untuk pengisian air tanah. Proporsi penggunaan pada wilayah Kota Tarakan tahun 2017 dapat dilihat pada Tabel 1. Penggunaan lahan wilayah Kota Tarakan untuk area hutan terdiri dari hutan belukar, hutan lebat, dan hutan rawa. Perubahan proporsi penggunaan lahan di wilayah Kota Tarakan sangat di pengaruhi oleh pertumbuhan penduduk yang semakin bertambah setiap tahun, sehingga dapat mengalami alih fungsi lahan hutan menjadi area pemukiman dan area lainnya. Zulkipli et al. (2012) dan Suhartanto et al. (2012) menyatakan bahwa perubahan proporsi penggunaan lahan pada suatu wilayah merupakan semua bentuk campur tangan manusia terhadap lahan dalam rangka memenuhi kebutuhannya. Peningkatan perubahan penggunaan lahan hutan menjadi permukiman dan tanah terbuka mengakibatkan berkurangnya tutupan lahan untuk pengisian air tanah. 
Tabel 1. Klasifikasi penggunaan lahan di Kota Tarakan Tahun 2017

\begin{tabular}{clcc}
\hline No. & \multicolumn{1}{c}{ Penggunaan Lahan } & Luasan (Ha) & Persentase \\
\hline 1 & Hutan & 10.507 & $41,89 \%$ \\
2 & Pemukiman & 7.815 & $31,16 \%$ \\
3 & Kebun & 684 & $2,73 \%$ \\
4 & campuran/semak/tegalan/ladang & 6.058 & $24,16 \%$ \\
5 & Lahan terbangun & 16 & $0,07 \%$ \\
\hline \multicolumn{2}{r}{ Tubuh air } & $\mathbf{2 5 0 8 0}$ & $\mathbf{1 0 0 \%}$ \\
\hline
\end{tabular}

\section{Presipitasi dan Evapotranspirasi}

Curah hujan merupakan salah satu unsur iklim yang sangat berpengaruh terhadap sektor pertanian. Pola distribusi hujan serta besarnya curah hujan sangat menentukan tipikal aktifitas pertanian. Curah hujan andalan yang digunakan dalam penelitian ini adalah curah hujan dengan peluang terlampaui $80 \%$, yang berarti bahwa kisaran nilai curah hujan mulai dari nol hingga nilai andalan dalam satu bulan memiliki peluang terlampaui sebesar $80 \%$. Curah hujan andalan $80 \%$ pada wilayah Kota Tarakan dapat dilihat pada Gambar 1.

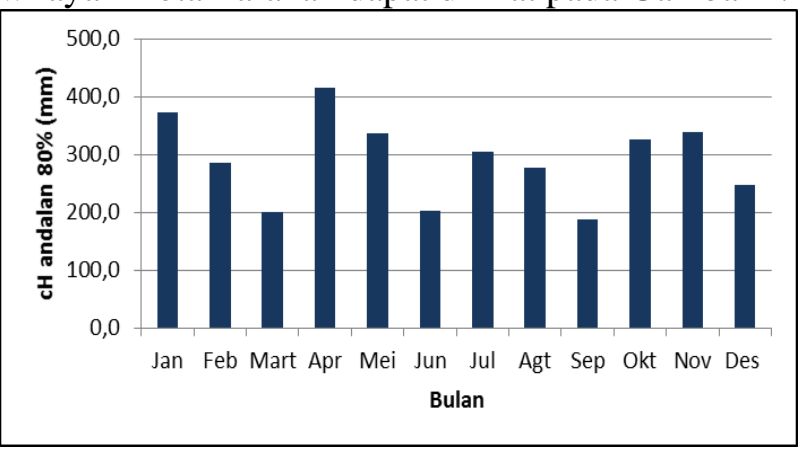

Gambar 1. Curah andalan $80 \%$ selama periode 2008-2017

Selama periode 2008-2017 wilayah Kota Tarakan memiliki total curah hujan andalan 3497,68 $\mathrm{mm} / \mathrm{tahun}$. Nilai rata-rata curah hujan andalan sebesar $291.47 \mathrm{~mm}$. Pada Gambar 1 menunjukkan bahwa curah hujan andalan terbesar terjadi di bulan April yaitu 416,32 mm, sedangkan curah hujan andalan terkecil terjadi pada bulan September yaitu $187,28 \mathrm{~mm}$. Berdasarkan hasil analisis bahwa bulan April dengan curah hujan maksimum berpotensi terjadinya banjir karena luapan air sungai dan besarnya potensi limpasan. Gambar 2 menunjukkan nilai evapotranspirasi potensial (ETp) untuk wilayah Kota Tarakan selama periode 2008-2017.

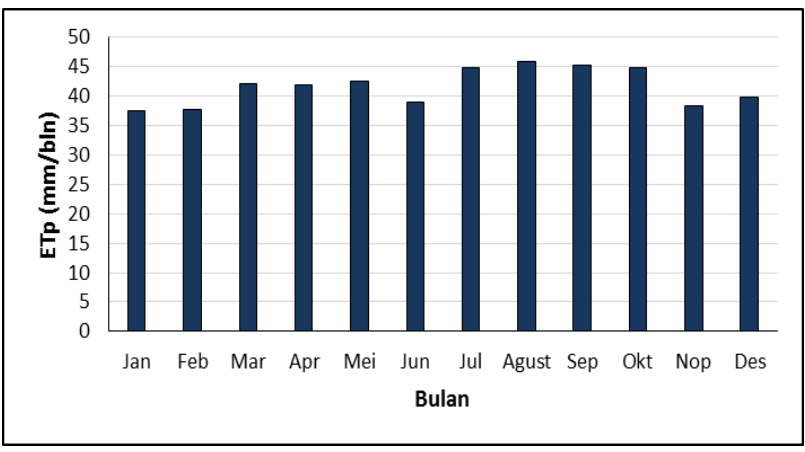

Gambar 2. Evapotranspirasi potensial selama periode 2008-2017

Evapotranspirasi acuan (ETo) dianalisis menggunakan software Cropwat 8.0 dengan data inputan berupa data temperatur, kelembaban relatif, kecepatan angin, dan lamanya penyinaran matahari untuk wilayah Kota Tarakan. Data tersebut diperoleh dari Stasiun Meteorologi Juwata Kota Tarakan Kalimantan Utara selama periode 2008-2017. Perhitungan nilai evapotranspirasi potensial (ETp) dilakukan dengan mengalikan nilai ETo dengan koefisien tanaman $(K c)$.

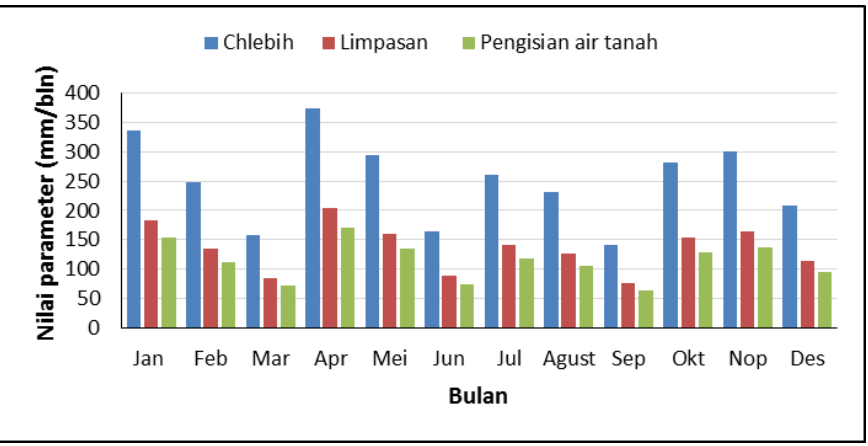

Berdasarkan hasil analisis bahwa nilai $\mathrm{Kc}$ untuk penggunaan lahan di wilayah Kota Tarakan selama periode 2008-2017 adalah 0,36. Pada Gambar 2 dapat dilihat bahwa evapotranspirasi potensial terbesar terjadi di bulan Agustus yaitu 45,86 $\mathrm{mm} /$ bulan, sedangkan evapotranspirasi potensial terkecil terjadi pada bulan Januari yaitu $37,46 \mathrm{~mm} /$ bulan. Evapotranspirasi potensial rata- 
rata di wilayah Kota Tarakan sebesar 41,65 $\mathrm{mm} / \mathrm{bulan}$. Nilai evapotranspirasi potensial sangat dipengaruhi oleh koefisien tanaman yang bergantung pada jenis tanaman, pertumbuhan tanaman, dan faktor iklim terutama temperatur.

\section{Analisis Neraca Air}

Analisis neraca air pada wilayah Kota Tarakan dilakukan berdasarkan data proporsi penggunaan lahan pada tahun 2017 menggunakan persamaan Tornthwaite. Hasil analisis dapat menggambarkan ketersediaan air (surplus atau defisit) terutama untuk keperluan bidang pertanian di wilayah Kota Tarakan. Persentase luasan area hutan sangat mempengaruhi jumlah air yang menjadi limpasan dan banyaknya air untuk pengisian air tanah. Hasil analisis neraca air pada wilayah Kota Tarakan dapat dilihat pada Gambar 3.

Gambar 3. Neraca air wilayah Kota Tarakan

Gambar 3 menunjukkah bahwa wilayah Kota Tarakan memiliki nilai rata-rata $\mathrm{Ch}_{\text {lebih }} 249,82$ $\mathrm{mm} /$ bulan, limpasan 135,86 $\mathrm{mm} / \mathrm{bulan}$, dan pengisian air tanah $113,96 \mathrm{~mm} / \mathrm{bulan}$. Nilai $\mathrm{CH}_{\text {lebih }}$, limpasan, dan pengisian air tanah dapat mengalami perubahan setiap tahunnya tergantung dari luasan penggunaan lahan. Jika persentase alih fungsi area hutan menjadi pemukiman dan area terbuka meningkat, maka akan terjadi peningkatan nilai limpasan dan penurunan nilai pengisian air tanah. Hal ini berpotensi terjadi ketidakseimbangan antara ketersediaan air dengan kebutuhan air di wilayah Kota Tarakan.

Tabel 2. Hasil analisis neraca wilayah Kota Tarakan

\begin{tabular}{|c|c|c|c|c|c|c|c|c|c|c|c|c|}
\hline \multirow{2}{*}{ Parameter $(\mathrm{mm})$} & \multicolumn{12}{|c|}{ Bulan } \\
\hline & Jan & Feb & Mar & Apr & Mei & Jun & Jul & Agust & Sep & Okt & Nop & Des \\
\hline Presipitasi (P) & 373,30 & 285,10 & 199,48 & 416,32 & 337,36 & 203,28 & 305,12 & 277,12 & 187,28 & 326,08 & 339,16 & 248,08 \\
\hline ETP & 37,46 & 37,71 & 42,16 & 41,94 & 42,59 & 39,03 & 44,79 & 45,86 & 45,18 & 44,90 & 38,37 & 39,82 \\
\hline P - ETP & 335,84 & 247,39 & 157,32 & 374,38 & 294,77 & 164,25 & 260,33 & 231,26 & 142,10 & 281,18 & 300,79 & 208,26 \\
\hline APWL & 0,00 & 247,39 & 404,71 & 779,09 & 1073,86 & 1238,10 & 1498,44 & 1729,70 & 1871,80 & 2152,98 & 2453,77 & 2662,03 \\
\hline STo & 87,88 & 87,88 & 87,88 & 87,88 & 87,88 & 87,88 & 87,88 & 87,88 & 87,88 & 87,88 & 87,88 & 87,88 \\
\hline Delta STo & 0,00 & 0,00 & 0,00 & 0,00 & 0,00 & 0,00 & 0,00 & 0,00 & 0,00 & 0,00 & 0,00 & 0,00 \\
\hline Evapotranspirasi aktual (ETa) & 37,46 & 37,71 & 42,16 & 41,94 & 42,59 & 39,03 & 44,79 & 45,86 & 45,18 & 44,90 & 38,37 & 39,82 \\
\hline Defisit (D) & 0,00 & 0,00 & 0,00 & 0,00 & 0,00 & 0,00 & 0,00 & 0,00 & 0,00 & 0,00 & 0,00 & 0,00 \\
\hline Surplus (S) & 335,84 & 247,39 & 157,32 & 374,38 & 294,77 & 164,25 & 260,33 & 231,26 & 142,10 & 281,18 & 300,79 & 208,26 \\
\hline Limpasan & 182,64 & 134,54 & 85,55 & 203,60 & 160,30 & 89,32 & 141,58 & 125,76 & 77,28 & 152,91 & 163,58 & 113,26 \\
\hline Pengisian air tanah & 153,20 & 112,85 & 71,76 & 170,78 & 134,47 & 74,93 & 118,76 & 105,49 & 64,82 & 128,27 & 137,21 & 95,00 \\
\hline
\end{tabular}

Tabel 2 dapat dilihat bahwa wilayah Kota Tarakan memiliki total $\mathrm{CH}_{\text {lebih }}$ sebesar 2997,86 $\mathrm{mm} / \mathrm{tahun}$, limpasan 1630,34 $\mathrm{mm} / \mathrm{tahun}$, dan pengisian air tanah 1367,54 mm/tahun. Secara umum strategi yang dapat dilakukan untuk mengembangkan pola tanam dan diversifikasi usahatani di Kota Tarakan yang hanya mengandalkan air hujan antara lain: (1) mengatur pola tanam dengan cara menyesuaikan ketersediaan air dan jenis tanaman yang akan dibudidayakan; (2) memanfaatkan curah hujan yang ada dan irigasi suplemen dengan komoditas yang sesuai, sehingga dapat meningkatkan intensitas tanam; (3) memilih pola tanam yang sesuai dengan karakteristik wilayah, seperti pola tumpangsari untuk mengurangi risiko kegagalan panen dan meningkatkan produksi dibandingkan dengan pola monokultur; dan (4) menggunakan paket teknologi usahatani yang sesuai dengan situasi iklim dan kondisi tanah di Kota Tarakan, seperti kombinasi penggunaan mulsa dengan varietas berumur genjah dan hemat air.

\section{KESIMPULAN}

Selama periode 2008-2017 wilayah Kota Tarakan memiliki total $\mathrm{CH}_{\text {lebih }}$ sebesar 2997,86 $\mathrm{mm} / \mathrm{tahun}$, limpasan $1630,34 \mathrm{~mm} / \mathrm{tahun}$, pengisian air tanah 1367,54 mm/tahun dan nilai ETp rata-rata $41,65 \mathrm{~mm} /$ bulan. Perubahan penggunaan area hutan menjadi pemukiman dan tanah terbuka akan mengakibatkan penurunan kapasitas simpan air untuk pengisian air tanah, hal ini berpotensi terjadi ketidakseimbangan antara ketersediaan dan kebutuhan air di wilayah Kota Tarakan.

\section{UCAPAN TERIMA KASIH}

Ucapan terima kasih disampaikan kepada Badan Meteorologi Klimatologi dan Geofisika, Stasiun Meteorologi Juwata Kota Tarakan Provinsi Kalimatan Utara atas bantuan dan kerjasama yang baik. Selain itu, ucapan terima kasih juga disampaikan kepada Ketua Program Studi Agroteknologi dan Dekan Fakultas Pertanian 
Universitas Borneo Tarakan atas dukungan dan bantuan administrasi.

\section{DAFTAR PUSTAKA}

Arsyad S. 2012. Konservasi Tanah dan Air. Ed. 2. Cetakan Ketiga. Bogor (ID): IPB Press.

Asdak C. 2010. Hidrologi dan Pengelolaan Daerah Aliran Sungai. Cetakan Kelima. Yogyakarta (ID): Gajah Mada University Press.

Djufry F. 2012. Pemodelan neraca air tanah untuk pendugaan surplus dan defisit air untuk pertumbuhan tanaman pangan di Kabupaten Merauke, Papua. Jurnal Informatika Pertanian. 21(1):1-9.

Kansil G. R., J. S. F. Sumarauw, L. Tanudjaja. 2015. Analisis neraca air sungai akembuala di Kota Tahuna Kabupaten Sangihe. Jurnal Sipil Statik. 3(7):503-514.

Pemerintah Daerah Kalimantan Utara. 2016. Rencana Pembangunan Jangka Menengah Daerah Provinsi Kalimantan Utara 2016-2021. Kalimantan Utara.

Pemerintah Daerah Kota Tarakan. 2016. Profil Kota Tarakan. Tarakan. Kalimantan Utara.

Prastowo. 2010. Daya dukung lingkungan aspek sumberdaya air. Working Paper P4W. Bogor (ID): Crestpent Press.

Siebert, S., Döll, P. (2010). Quantifying blue and green virtual water contents in global crop production as well as potential production losses without irrigation. Journal of Hydrology, 384(3), 198-217.

Suhartanto E., L.M. Limantara, A. Samosir. 2012. Water balance analysis at sub watershed of wirway irrigation Sarmi Regency, Papua Province. Jurnal Irigasi. 7(2):74-86.

Thornthwaite CW., Mather JR. 1957. Instruction and Table for Computing Potensial Evapotranspiration and Water Balance. New Jersey. Centerton.

Triatmodjo B. 2013. Hidrologi Terapan. Cetakan Ketiga. Yogyakarta (ID): Beta Offset.

Zulkipli, W. Soetopo, H. Prasetijo. 2012. Analisa neraca air permukaan DAS Renggung untuk memenuhi kebutuhan air irigasi dan domestik penduduk Kabupaten Lombok Tengah. Jurnal Teknik Pengairan. 3(2):87-96. 